\title{
Psychological Quality of Life in People with Physical Disability: The Effect of Internalized Stigma, Collective Action and Resilience
}

\author{
Prado Silván-Ferrero®, Patricia Recio®, Fernando Molero and Encarnación Nouvilas-Pallejà * \\ Faculty of Psychology, National University for Distance Education (UNED), 28040 Madrid, Spain; \\ mdpsilvan@psi.uned.es (P.S.-F.); reciop@psi.uned.es (P.R.); fmolero@psi.uned.es (F.M.) \\ * Correspondence: enouvilas@psi.uned.es; Tel.: +34-913-987-955
}

Received: 17 December 2019; Accepted: 6 March 2020; Published: 10 March 2020

\begin{abstract}
Purpose: The main objective of this study was to examine the role of social identification, collective action and resilience in reducing the negative consequences of internalized stigma on the psychological quality of life of people with physical disability using path analysis. We propose a model with two paths: the first through social identification and collective action and the second via resilience. Method: A total of 288 Spanish people with physical disability aged between 18 and 82 years $(46.4 \%$ males; mean [SD] of age $=45.1$ [12.3] responded to the questionnaire. Data were collected for three months through an online survey. Results: The tested model adequately fit the data. We found that the relationship between internalized stigma and the psychological quality of life of people with physical disability was mediated by resilience. However, neither social identification nor collective action mediated the association between internalized stigma and quality of life among our participants. Conclusions: The results confirmed the negative association between internalized stigma and quality of life in the population with physical disability. The results show that some interactive processes, such as resilience, may contribute to decreasing the negative effects of internalized stigma. In contrast, no effects of identification with the group or collective action intention were found.
\end{abstract}

Keywords: resilience; internalized stigma; collective action; disability; quality of life

\section{Introduction}

In 1963, Goffman [1] defined stigma as a discrediting attribute that places a subject into a different and undesirable category. From this initial conceptualization, the definition of this term has evolved to highlight the importance of the situational component in addition to observable characteristics. Another definition highlights the role of a specific social context in devaluating a stigmatized person [2]. That is, it is necessary to consider the context in which stigmatization occurs in addition to observable physical characteristics. [3] defined stigma as "a social construction" that includes the recognition of a difference based on a branding and the subsequent devaluation of a person. Stigma assumes the existence of a negative status established in society and negative attitudes that lead to discriminatory behaviour towards a stigmatized group $[4,5]$.

Previous research reveals that people with disability in their daily living may encounter unfriendly treatment and are at risk of being stigmatized, e.g., [6,7]. Stigma towards this group can be reflected in different ways, such as the experience of discomfort or anxiety in social interactions with this group [8] or in negative stereotypes in which people with disability are different from fully human people [9]. Perceived discrimination may have negative effects on the well-being of people with disability [10], but the worst consequence is the internalization of stigma [11].

Internalized stigma is defined as the acceptance of stigma by a stigmatized person as part of the person's own system of values and self-concept [12]. Studies on the groups with high levels of stigma, 
such as people with mental illness [13-20] or family members of people with mental illness [21-26], children with learning disabilities [27], people with epilepsy [28], people with weight concerns [29-39], and people with HIV [40-42] highlight the highly negative effects of internalized stigma. However, so far, research on the internalized stigma of people with disability and its consequences is scarce. Recent research has shown the mediating effect of internalized stigma on the relationship between perceived personal discrimination and self-esteem in people with disability [43].

The negative impact of internalized stigma on quality of life has been found in some previous research examining stigmatized groups. In the case of mental illness, the link between internalized stigma and quality of life has been well established. For example, [44] found a theoretical model of the relationship between internalized stigma and quality of life, which was mediated by a sense of coherence and self-esteem. Similarly, [45] showed that internalized stigma is a predictor of lower quality of life in different areas of life (work/occupation, leisure time and mental health) in outpatients with bipolar disorder.

The main goal of this paper is to examine the role of two different strategies that can reduce the negative consequences of internalized stigma for the psychological quality of life in people with physical disability in Spain using structural equation modelling. The first path is through group identification and collective action, and the second path is via resilience to promote a positive psychological quality of life in people with disability.

\subsection{The Rejection-Identification Model}

As stated before, the first path we propose to reduce the negative influence of internalized stigma is via group identification and collective action. The rejection-identification model (RIM) [46] posits that perceived group discrimination increases in-group identification, which in turn prevents some of the negative effects of discrimination. Thus, social identification can play a protective role between perceived discrimination and its negative consequences, as has been shown in different groups [46-50]. However, the RIM has received incomplete support in some studies that differentiate between individual and group discrimination [51-53], while other studies provide no support for the model [54,55].

Previous research points out that group identification can be a precondition for collective action [56-58]. Thus, members who identify more strongly with their group are more likely to engage in collective action in order to improve their status. The association between group identification and collective action is supported by ample evidence in various stigmatized groups [11,59-62]. In people with several types of disability, group identification was found to predict involvement in political organizations with the aim to improve their status [63]. However, there is no clear evidence of the influence that collective action may have on well-being. Positive effects were found in people with HIV [64] and in lesbians and gay people [62], but for people with mental illness, collective action was positively and negatively associated with well-being [11].

In this research, we examine disability from a social identity perspective [59] considering social identification as a precondition for collective action. Based on this theoretical framework, we expect that internalized stigma may enhance group identification, which in turn may strengthen collective action tendencies. That is, the link between group identification and collective action may reduce the negative effects of internalized stigma on psychological quality of life.

\subsection{Resilience, Stigma and Quality of Life}

Resilience, as a theoretical construct, is difficult to conceptualize. A classic definition considers resilience a "universal capacity which allows a person, group or community to prevent, minimize or overcome the damaging effect of adversity" [65], p. 4. Thus, resilience supports the development of social, academic and emotional competence despite exposure to stressful situations and substantial difficulties. 
Researchers use this concept when referring to a socially competent person with identity consciousness who is able to make decisions; has aims and life goals; can satisfy his or her basic affect, relationship and respect needs and can grow through adversity and disruption [66-69]. However, resilience is not a trait but an interactive process: It is a set of intrapsychic and social processes that occur over time by combining personal attributes and the social and cultural environment [69-72]. Thus, [73] defined resilience as "the role of mental processes and behaviour in promoting personal assets and protecting an individual from potential negative effects of stressors" (p. 16).

Resilience studies are fundamentally linked to adversity, as the main antecedent, and positive adaptation, as the main consequence [73]. For example, some authors have considered that resilience in the adversity context is dynamic and encompasses positive adaptation [74,75]. Davidov and his collaborators (2013) noted that resilience can be defined as synonymous with reduced vulnerability, with the ability to adapt to or cope with adversity [76-78]. However, it is important to note the distinction between resilience and coping [74]. For example, in Lazarus and Folkman's (1984) definition [79], coping is conceived as the efforts made by a person "to manage specific external demands that are appraised as taxing or exceeding the person's resources" (p. 141). Thus, resilience is involved in a person's evaluation of a stressful event, whereas coping refers to the strategies that a person employs to face a stressful event. Furthermore, resilience is a response with a positive direction, whereas this is not necessarily the case with coping strategies.

The effects of protective and promotive factors vary contextually and temporally $[66,74,80]$. The sociocultural context is important when examining positive adaptation, and it can change throughout a situation and across an individual's lifespan. With respect to time, there are significant differences between age groups in favour of older people versus middle-aged and young people [81].

Given the importance of the interaction between people and their environment, we should understand the important role of resilience in the stress process. Lazarus's cognitive-motivational-relational theory (1991) [79] and, subsequently, a meta-model on stress, emotion, and performance proposed by Fletcher and Scott [82] describes how an individual reacts to stressful situations. The model also explains how an individual's action affects his/her performance $[73,74,83]$ with the conceptualization that stressors increased in the individual's environment. Specifically, processes of perception, appraisal and coping are potential mediators given that they could result in positive or negative responses and different types of feeling states. There are several situational and personal characteristics (positive affect, self-efficacy, self-esteem) that moderate the ongoing process. Specifically, "resilience-related variables can influence the stress process in the individual appraisal of stressors, his meta-cognitions and his selection of coping strategies" (p. 16). In fact, it has been shown that a higher degree of resilience is associated with better quality of life and a lower degree of internalized stigma in patients with schizophrenia [84-86]. In bipolar patients, resilience is a predictor of overall quality of life [45]. In general, it is believed that the psychosocial aspects associated with resilience explain this association [87].

People with disability (motor or sensory) are in a difficult situation: they face barriers in their daily activities and have an increased risk of developing various symptoms, stigma and secondary maladies (e.g., fatigue, depression, pain). It is necessary to identify protective factors that could help these people function healthily and improve their quality of life despite these barriers [88]. Resilience may play an important role for people who encounter many difficult barriers in their everyday life functioning [89].

Although little work has focused on the role of resilience in adult people with disability [66,69,88-91], resilience can produce some responses that demonstrate the relevance of this factor in difficult situations. A study found that depression was significantly associated with lowered resilience among people with disability [91]. Another study found that a decrease in resilience was associated with an increase in depression and fatigue, whereas an increase in resilience was associated with sleep quality and physical functioning in ageing people with disability [89]. However, [88] found that physical functioning was not strongly influenced by resilience. 
These different results show the need for more research to clarify how resilience can influence the way that people with disability face their situation and overcome barriers to experience a better quality of life.

\subsection{Goals and Hypotheses}

The present research aims to examine the consequences of internalized stigma for the psychological quality of life of people with physical disability using path analysis. We propose a model (Figure 1) in which internalized stigma is related to psychological quality of life by means of two pathways that may constitute two ways to cope with stigma. The first path is collective/external in nature, and the second is of an internal nature.

In the current study, we examine whether group identification, collective action and resilience mediate the association between internalized stigma and psychological quality of life of people with physical disability. As shown in Figure 1, we hypothesize a multiple mediation model in which we expect that group identification and collective action mediate the association between internalized stigma and psychological quality of life. We further hypothesize that resilience mediates the relation between internalized stigma and psychological quality of life.

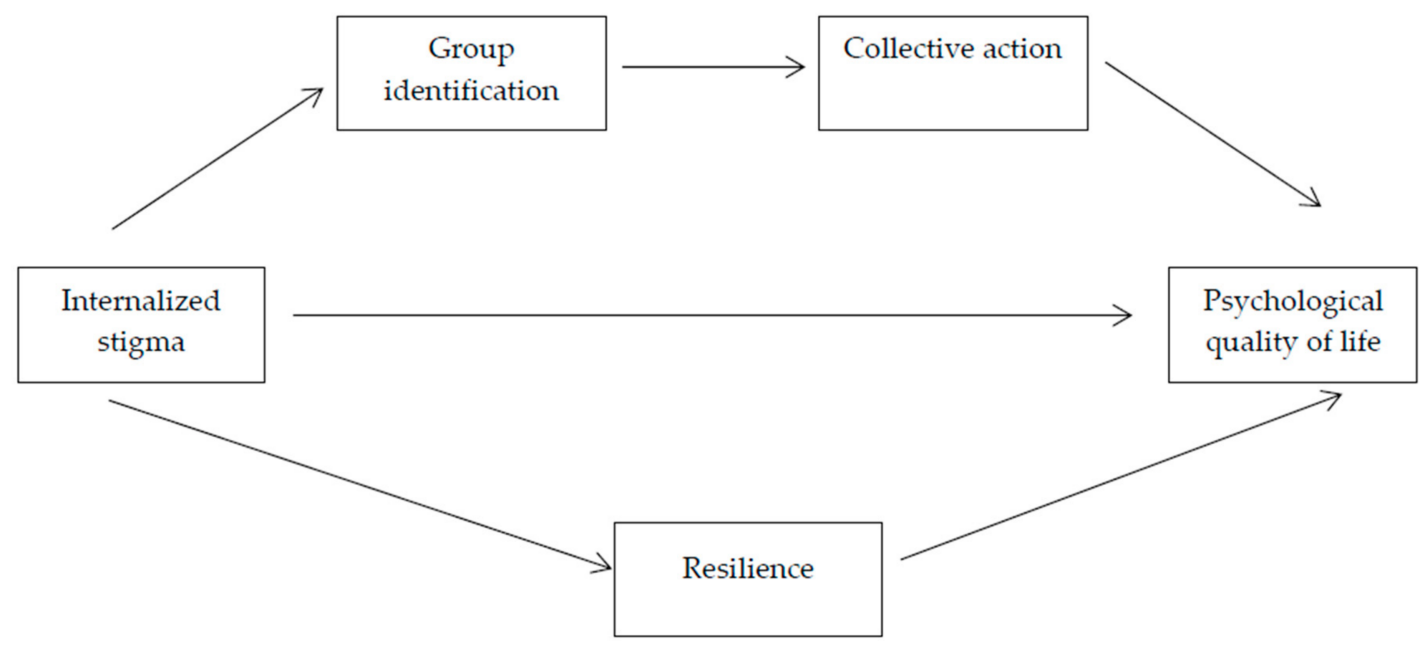

Figure 1. Model of psychological quality of life in people with disability.

\section{Method}

\subsection{Participants}

The participants were 289 Spanish people (46.4\% men and 53.3\% women) with physical disability. Their age ranged between 18 and 82 years $(M=45.1 ; S D=12.3)$. All participants had their disability certified according to the Spanish administration's Royal Decree law 1971/1999 of December 23. Among the participants, $72 \%$ were between $33 \%$ and $65 \%$ disabled (which allowed them to obtain a Disability Certificate that gives them access to some benefits, rights and services), and $28 \%$ were more than $65 \%$ disabled (which means they qualified for a non-contributory pension). Most had secondary education or vocational training (47.9\%); the rest had higher education $(26.9 \%)$, primary education $(22.7 \%)$ or no formal education $(2.4 \%)$.

\subsection{Measures}

Stigma scale for chronic illness 9-item version (SSCI-9). The Spanish adaptation of the internalized stigma subscale of the SSCI [92], which had shown adequate psychometric properties in a of people with different disabilities, was used for the research [93,94]. Example items are "Because of my illness, I feel emotionally distant from other people" and "Because of my illness, I feel embarrassed in social situations". Each item is rated on a four-point scale that ranges from 1 (never or almost never) to 4 
(always or almost always), and total scores range from 9 to 36 . Higher scores indicate higher levels of stigma. In our study, the scale showed good internal consistency, with a Cronbach's alpha value of 0.91 and a composite reliability (CR) value of 0.91 .

Group identification. We measured identification using the Spanish version [60] of a previously validated six-item measure [95]. Participants responded to each item by indicating the degree to which they agreed with it on a 4-point Likert scale. Sample items are "When someone criticizes people with my same disability, it feels like a personal insult" and "I am very interested in what others think about people with disability". The alpha coefficient for this scale was 0.82 , and CR was 0.85 .

Collective action. Four items were used to assess the collective action, including its perceived effectiveness and the intention to perform it [62]. An example item is "I am willing to participate in collective actions to support the rights of people with disability". Participants were requested to respond on a 4-point Likert scale ranging from 1 (no agreement) to 4 (totally agree). In the current study, the internal consistency results showed good reliability $(\alpha=0.80$ and $C R=0.81$ ).

Resilience. The 10-item Conner-Davidson Resilience Scale was used to assess resilience [96], a self-administered questionnaire with a Likert-type additive scale containing four response options (from $0=$ never to $4=$ almost always). The original version had a single dimension. Example items are "Under pressure, I focus and think clearly" and "I am not easily discouraged by failure". We used the Spanish version [97], which showed adequate reliability in our sample ( $\alpha=0.90$ and $C R=0.92)$.

Psychological quality of life. We used the subscale of the psychological domain of the Spanish adaptation of the short version of the WHO quality of life questionnaire (WHOQOL-BREF) [98,99]. Example items are "How much do you enjoy life?" and "To what extent do you think your life makes sense?" The six items that composed the subscale were answered on a five-point scale, with high scores representing higher quality of life in the psychological domain (with item 26 reverse coded). In our study, the scale showed good internal consistency (Cronbach's alpha $=0.80$ and $C R=0.83$ ).

\subsection{Procedure}

Undergraduate students majored in psychology in a Spanish university (i.e., Universidad Nacional de Educación a Distancia (UNED; National Open University)) assisted in participants recruitment personally. The students identified the target participants (i.e., those with physical disability) and explained study objections together with instructions for questionnaire completion to them. The collection period was three months. Participants were guaranteed anonymity and confidentiality. Once they had registered and filled in the consent form, participants completed the questionnaire for approximately 20-30 min online using Qualtrics software. The research was previously approved by the University Ethics Committee and developed following the ethical standards of the Declaration of Helsinki.

\subsection{Statistical Analysis}

First, a preliminary analysis was carried to determine the descriptive statistics and correlations between the variables in order to understand the basic properties and the relationships between the variables. Next, path analysis was used to test the proposed model using AMOS 24 (IBM CORP, Lincoln, NE, USA). Model estimations used maximum likelihood estimation, so multivariate normality was statistically evaluated by critical ratio of multivariate kurtosis proposed by Mardia, where a critical ration below suggests multivariate normality. A critical ratio of kurtosis $<5.0$ indicates multivariate normality [100]. We found a Mardia's coefficient equal to -0.87 ; therefore, our data showed a multivariate normal distribution. Calculation of the Mahalanobis distance revealed no multivariate outliers in the sample. The indexes of fit included $\chi^{2} / \mathrm{df}$ (good fit $<3$ ) and the Root Mean Square Residual (RMR), both used as indexes of absolute fit (there is a good model fit if RMR is less than or equal to 0.05 , and there is adequate fit if RMR is less than 0.08). The Normed Fit Index (NFI) and Comparative Fit Index (CFI) were used as indexes of incremental fit, both ranging from 0 to 1 ; 
values between 0.90 and 0.95 indicate an acceptable model fit, and values greater than 0.95 indicate a close model fit [101].

Finally, a bias-corrected bootstrapping procedure was used to assess mediation effects. Mediation assessing through bootstrap method is advocated as the best approach because of its reliable estimates and valid confidence intervals for both direct and indirect effects. Through random sampling method, 10,000 resamples were generated from the original dataset. A significantly indirect effect in the bootstrapping method has its $95 \%$ confidence interval not cover zero. After comparing the significance of direct effect with and without mediators, a total mediation "(i.e., direct effect becomes nonsignificant) or a partial mediation (i.e., direct effect keeps significant)."

With the percentage of missing values below $2 \%$, imputation is not necessary, and the final sample size used in the structural equation modelling was 275 . The sample size is sufficient in providing accurate estimates, standard errors, and fit statistics [102]. Although there are no definitive rules concerning the necessary sample size for SEM techniques [103], most researchers suggest a minimum of 100-200 cases, or 10 cases per parameter estimate [104]. Our model contained 17 parameters to be estimated, so our final sample $(n=275)$ was adequate.

\section{Results}

Table 1 shows the descriptive statics of the studied variables and their bivariate correlation coefficients. We assessed the associations between internalized stigma, group identification, collective action, resilience and psychological quality of life. All correlations were significant except for the relationships between group identification and resilience, between group identification and psychological quality of life and between internalized stigma and collective action.

Table 1. Descriptive statistics and Pearson correlation coefficients for the variables in the study.

\begin{tabular}{lccccccc}
\hline & $\mathbf{M}$ & SD & $\mathbf{1}$ & $\mathbf{2}$ & $\mathbf{3}$ & $\mathbf{4}$ & $\mathbf{5}$ \\
\hline 1. Internalized stigma & 1.98 & 0.71 & - & $0.18^{* *}$ & -0.01 & $-0.55^{* *}$ & $-0.51^{* *}$ \\
2. Group identification & 2.69 & 0.78 & - & $0.53^{* *}$ & 0.07 & 0.03 \\
3. Collective action & 3.16 & 0.69 & & & - & $0.23^{* *}$ & 0.13 \\
4. Resilience & 3.00 & 0.63 & & & - & $0.62^{* *}$ \\
5. Psychological quality of life & 3.34 & 0.55 & & & - \\
\hline Notes. Scores ranged from 1 to 4, except for psychological quality of life (which ranged from 1 to 5). ${ }^{* *} p<0.01$.
\end{tabular}

\subsection{Model Testing}

The results showed that the hypothesized model fit the data reasonably well, except those related to $\chi^{2}$ value, which are greatly influenced by the sample size [51]: $\chi^{2}=25.52, \mathrm{df}=4, \mathrm{CFI}=0.951$, $\mathrm{NFI}=0.944$ and $\mathrm{RMR}=0.047$. Modification index shown by AMOS recommended adding a path between activism and resilience to the model. After considering the theoretical feasibility of this change and verifying that there is a significant correlation between both variables (see Table 1), this change was introduced in the model and the analysis was carried out again. The final model can be seen in Figure 2. Overall, the model presented an excellent model fit to the data: the $\chi^{2}$ value was not significant $\left(\chi^{2}=5.79, p=0.122\right)$, CFI was 0.994, NFI was 0.987 and RMR was 0.019 .

As shown in Figure 2, internalized stigma was positively related to group identification ( $\beta=0.18$, $p=0.002)$, which in turn was related to activism $(\beta=0.53, p<0.001)$. However, collective action did not predict psychological quality of life $(\beta=0.04, p=0.310)$. Collective action was positively related to resilience ( $\beta=0.22, p<0.001$ ). On the other hand, as we hypothesized, internalized stigma was negatively related to resilience $(\beta=-0.55, p<0.001)$, which in turn was positively related to psychological quality of life $(\beta=0.52, p<0.001)$. 


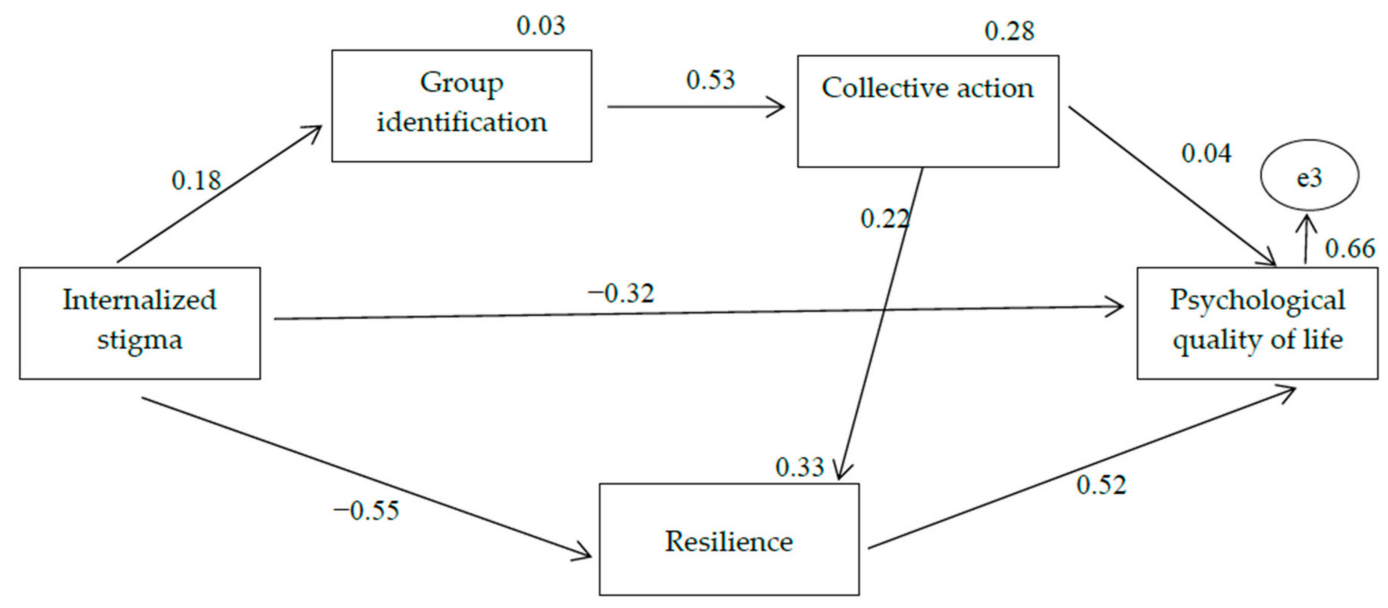

Figure 2. Standardized regression coefficients of the proposed model. Note: The percentage of explained variance is indicated in italics above the variable. All direct effects were significant $(p<0.01)$, except $\beta=0.04(p=0.31)$.

\subsection{Mediation Analyses}

There was no mediating effect of the variables of group identification and collective action on the relationship between internalized stigma and psychological quality of life because there was no relationship between activism and psychological quality of life $(\beta=0.04, p=0.310)$. As shown in Table 2, we found a significant indirect effect of internalized stigma on resilience via group identification and collective action ( $\beta=0.021, p<0.001 ; 95 \%$ CI: $0.008,0.043)$. However, there was no mediating effect because the relationship between internalized stigma and resilience did not decrease when group identification and collective action were introduced into the model. Furthermore, there was no mediating effect of group identification on the relationship between internalized stigma and collective action because there was no direct relationship between the two variables $(\beta=-0.010, p=0.859)$, so there was no reason to check the mediating effect.

Table 2. Results of mediational analysis.

\begin{tabular}{ccccc}
\hline Mediational Analysis & & $\begin{array}{c}\text { Direct Beta } \\
\text { without Mediator }\end{array}$ & $\begin{array}{c}\text { Direct Beta } \\
\text { with Mediator }\end{array}$ & Indirect Beta [CI] \\
\hline $\mathrm{IE} \rightarrow \mathrm{GI}$ and CA $\rightarrow$ Resilience & No mediation & $-0.53^{* * *}$ & $-0.55^{* * *}$ & $0.02 * *[0.008-0.043]$ \\
$\mathrm{IE} \rightarrow \mathrm{GI} \rightarrow \mathrm{CA}$ & No mediation & -0.01 & $0.09^{* *}$ & $0.03[0.036-0.158]$ \\
$\mathrm{IE} \rightarrow$ Resilience $\rightarrow$ PQL & Partial mediation & $-0.61^{* * *}$ & $-0.32^{* * *}$ & $-0.29^{*}[-0.223--0.371]$ \\
\hline
\end{tabular}

Note: IE, Internalized Stigma; GI, Group Identification; CA, Collective Action; PQL, Psychological Quality of Life.

There was an indirect relationship between internalized stigma and psychological quality of life mediated by resilience. To analyse the type of mediation, we restricted the paths from internalized stigma to resilience and from resilience to psychological quality of life to 0 in the direct model. In this case, the direct relationship between internalized stigma and psychological quality of life was $\beta=-0.60$ $(p<0.001)$, and it decreased to $\beta=-0.32(p<0.001)$ when resilience was introduced into the model (partial mediation). The bootstrapping results revealed that the mediating effect of resilience produced an indirect relationship ( $\beta=-0.293, p<0.001 ; 95 \% \mathrm{CI}:-0.223,-0.371)$.

\section{Discussion}

The main objective of this research was to examine the consequences of internalized stigma for the psychological quality of life of people with physical disability. In our proposed model, internalized stigma was related to psychological quality of life by means of two pathways that may constitute two ways to cope with stigma: first, through group identification and collective action; second, through resilience. 
The results showed, first, that the proposed model offered an adequate fit to the data. Second, the relationship between internalized stigma and the psychological quality of life of people with physical disability was partially mediated by resilience. However, social identification and collective action were not mediators in the relationship between internalized stigma and quality of life.

Our results confirm the negative association between internalized stigma and quality of life in people with physical disability. This association, which has previously been found in other stigmatized groups, such as people with mental illness [44,45], can also be applied to people with physical disability.

Our data also show the mediating role of some interactive processes, such as resilience, in reducing the negative effects of internalized stigma on psychological quality of life. Previous longitudinal studies have shown that resilience is a factor that promotes successful ageing in people with physical disability [105]. In relation to motor disability, it is possible to identify different profiles of resilience, and low resilience profiles are related to a deficit in psychological adjustment and quality of life in general $[69,106]$. In fact, previous studies have shown the mediation effect of resilience on the demands associated with living with disability on quality of life both in adolescents with disability and their parents [64] as well as its moderating role in the relationship between affective disorders and quality of life in young adults with multiple sclerosis [107]. Although some research finds no influence of resilience on physical functioning [88], our study shows that this variable can reduce the negative effects of internalized stigma on the psychological quality of life of people with disability.

Although our data show that internalized stigma enhances group identification, which in turn promotes collective action, this link between group identification and collective action does not mediate the relationship between internalized stigma and psychological quality of life. However, in our sample, although group identification increased collective action tendencies, this did not seem to have protective effects on psychological quality of life. Research on other groups [62] has revealed the positive effect of collective action tendencies on well-being and on self-esteem in people with disability [75]. Despite this, collective action associates positively with resilience in our sample. Previous research [107] have explored the moderator role of resilience and collective action on psychological distress in a transgender sample, finding no moderation effects. More studies addressed on these relations is needed.

\subsection{Practical Implications}

From our results, we can conclude that to promote a better psychological quality of life for people with physical disability, the strengths developed through coping with daily barriers contribute to a greater extent than other variables, such as the perceived effectiveness of collective action and the intention to engage in it.

The disability paradox [108] emphasizes the importance of personal experience with disability in defining people's self, their view of the world, their social context and their social relationships. These personal experiences may explain why people with a persistently serious disability report satisfactory quality of life even though other external observers consider that they may have an unfavourable living situation. [109].

In the same vein as the disability paradox, in our sample, participants reported good levels of psychological quality of life and resilience. Moreover, resilience reduced the negative effects of internalized stigma. This means that disability itself did not decrease a disabled individual's quality of life and that an individual's capacity to cope with everyday life may also be of great importance [61,110].

Our results show the need to implement intervention programmes aimed at improving the psychological quality of life of people with disability by promoting resilience. This can be achieved in two ways; first, developing activities that promote personal resources to allow good adaptation to disability and, second, encouraging people with disability to apply coping strategies adapted to the concrete context of their disability. The pain acceptance programs, such as the Acceptance Commitment Therapy [111], may tackle the chronic pain and further elevate the functional status as well as emotional and physical well-being $[112,113]$. Resilience intervention has also shown positive results in people with diabetes [114,115], after suffering a stroke [116] and as therapy for parents or 
other people who care for people with disabilities [117,118] or chronic illnesses [119]. In general, the results show the positive effects of resilience intervention on reducing stress and improving the ability to cope with stressful conditions, thus overall improving wellbeing and quality of life. However, some authors have noted concerns about universal resilience interventions [120], such as the possibility of focusing on the individual and overlooking environmental aspects. Therefore, it is necessary to provide resilience interventions adapted to the characteristics of the disability and the variables studied in applied research $[121,122]$.

\subsection{Limitations}

This study has several limitations. First, our sample was voluntary in nature, which may imply different motivations to participate in the research. Second, the sample did not include all degrees of disability since the higher level was underrepresented. We did not consider additional diagnoses in the studied sample, such as depression, PTSD/trauma, and substance use, at the time of participation. These factors could affect stigma perception and consequently psychological quality of life. We also did not examine life and biomedical variables related to adaptation to the course of the disease [123].

Further research should use samples with different types, levels and grades of disability. Differences may be identified regarding the severity of the disability. It should also be considered whether a disability is congenital or acquired because this difference can produce different environmental adaptations to the disability. Longitudinal studies should be conducted to explore the mediating role of resilience over time to identify whether personal strengths evolve over the course of disability.

\section{Conclusions}

First, this study shows the negative association between internalized stigma and quality of life in people with physical disability. Second, our research reveals the mediator role of resilience in the relationship between internalized stigma and the psychological quality of life of people with physical disability. The results show that some interactive processes, such as resilience, may contribute to decreasing the negative effects of internalized stigma. Intervention programmes aimed to improve psychological quality of life of people with disability should promote resilience adapted to the characteristic of the disability.

Author Contributions: Conceptualization, P.S.-F. and E.N.-P.; methodology, P.R.; formal analysis, P.R.; data curation, P.R.; writing-original draft preparation, P.S.-F. and E.N.-P.; supervision, F.M.; project administration, F.M. and P.R.; funding acquisition, F.M. All authors have read and agreed to the published version of the manuscript.

Funding: This research was funded and supported by Spanish Ministry of Economy and Competition under Grant PSI2013-43343-R.

Conflicts of Interest: The authors declare no conflict of interest. The funders had no role in the design of the study; in the collection, analyses, or interpretation of data; in the writing of the manuscript, or in the decision to publish the results.

\section{References}

1. Goffman, E. Stigma: Notes on the Management of Spoiled Identity; PrenticeHall: Englewood Cliffs, NJ, USA, 1963.

2. Crocker, J.; Major, B.; Steele, C. Social stigma. In Handbook of Social Psychology, 4th ed.; Gilbert, D.T., Fiske, S.T., Eds.; McGrawHill: Boston, MA, USA, 1998.

3. Dovidio, J.F.; Major, B.; Crocker, J. Stigma: Introduction and overview. In The Social Psychology of Stigma; Heatherton, T.F., Kleck, R.E., Hebl, M.R., Hull, J.G., Eds.; The Guilford Press: New York, NY, USA, 2000.

4. Hebl, M.R.; Dovidio, J.F. Promoting the "Social" in the Examination of Social Stigmas. Pers. Soc. Psychol. Rev. 2005, 9, 156-162. [CrossRef]

5. Chang, C.C.; Lin, C.Y.; Gronholm, P.C.; Wu, T.H. Cross-validation of two commonly used selfStigma measures, Taiwan versions of the Internalized Stigma Mental Illness scale and SelfStigma ScaleShort, for people with mental illness. Assessment 2018, 25, 777-792. [CrossRef] 
6. Krahe, B.; Altwasser, C. Changing negative attitudes towards persons with physical disability: An experimental intervention. J. Community Psychol. 2006, 16, 59-69. [CrossRef]

7. Park, J.H.; Faulkner, J.; Schaller, M. Evolved diseaseAvoidance processes and contemporary antiSocial behavior: Prejudicial attitudes and avoidance of people with physical disability. J. Nonverbal Behav. 2003, 27, 65-87. [CrossRef]

8. Hebl, M.R.; Tickle, J.; Heatherton, N.T.F. Akwards moments in interactions between nonstigmatized and stigmatized individuals. In The Social Psychology of Stigma; Heatherton, T.F., Kleck, R.E., Hebl, M.R., Hull, J.G., Eds.; The Guilford Press: New York, NY, USA, 2000.

9. Block, L. Stereotypes about People with Disability. Available online: https://www.disabilitymuseum.org/ dhm/edu/essay.html?id=24 (accessed on 16 January 2020).

10. Barg, C.J.; Armstrong, B.D.; Hetz, S.P.; Latimer, A.E. Physical disability, stigma, and physical activity in children. Int. J. Disabil. Dev. Educ. 2010, 57, 371-382. [CrossRef]

11. Pérez-Garín, D.; Molero, F.; Bos, A.E.R. The effect of personal and group discrimination on the subjective well-being of people with mental illness: The role of internalized stigma and collective action intention. Psychol. Health Med. 2017, 22, 406-414. [CrossRef] [PubMed]

12. Herek, G.M.; Gillis, J.R.; Cogan, J.G. Internalized stigma among sexual minority adults: Insights from a social psychological perspective. J. Couns. Psychol. 2009, 56, 1-32. [CrossRef]

13. Cavelti, M.; Kvrgic, S.; Beck, E.M.; Rüsch, N.; Vauth, R. SelfStigma and its relationship with insight, demoralization, and clinical outcome among people with schizophrenia spectrum disorders. Compr. Psyquatry 2012, 53, 468-479. [CrossRef]

14. Cheng, C.M.; Chang, C.C.; Wang, J.-D.; Chang, K.C.; Ting, S.Y.; Lin, C.Y. Negative impacts of selfStigma on the quality of life of patients in methadone maintenance treatment: The mediated roles of psychological distress and social functioning. Int. J. Environ. Res. Public Health 2019, 16, 1299. [CrossRef]

15. Chang, K.C.; Lin, C.Y.; Chang, C.C.; Ting, S.Y.; Cheng, C.M.; Wang, J.-D. SelfStigma, psychological distress, and quality of life in opioid-dependent individuals. PLOS ONE 2019, 14, e0211033.

16. Huang, W.Y.; Chen, S.P.; Pakpour, A.H.; Lin, C.Y. The mediation role of self-esteem for selfStigma on quality of life for people with schizophrenia: A retrospectively longitudinal study. J. Pac. Rim Psychol. 2018, 12, e10. [CrossRef]

17. Lin, C.Y.; Chang, C.C.; Wu, T.H.; Wang, J.-D. Dynamic changes of selfStigma, quality of life, somatic complaints, and depression among people with schizophrenia: A pilot study applying kernel smoothers. Stigma Health 2016, 1, 29-43. [CrossRef]

18. Chang, C.C.; Wu, T.H.; Chen, C.Y.; Lin, C.Y. Comparing internalized stigma between people with different mental disorders in Taiwan. J. Nerv. Ment. Dis. 2016, 204, 547-553. [CrossRef]

19. Wu, T.H.; Chang, C.C.; Chen, C.Y.; Wang, J.-D.; Lin, C.Y. Further psychometric evaluation of the SelfStigma ScaleShort: Measurement invariance across mental illness and gender. PLoS ONE 2015, 10, e0117592. [CrossRef]

20. Chang, C.C.; Wu, T.H.; Chen, C.Y.; Wang, J.-D.; Lin, C.Y. Psychometric evaluation of the Internalized Stigma of Mental Illness Scale for patients with mental illnesses: Measurement invariance across time. PLoS ONE 2014, 9, e98786. [CrossRef] [PubMed]

21. Saffari, M.; Lin, C.Y.; Koenig, H.G.; O'Garo KG, N.; Broström, A.; Pakpour, A.H. A Persian version of the Affiliate Stigma Scale in caregivers of people with dementia. Health Promot. Perspect. 2019, 9, 31-39. [CrossRef]

22. Chang, C.C.; Su, J.A.; Chang, K.C.; Lin, C.Y.; Koschorke, M.; Thornicroft, G. Perceived stigma of caregivers: Psychometric evaluation for Devaluation of Consumer Families Scale. International. J. Clin. Health Psychol. 2018, 18, 170-178. [CrossRef]

23. Chang, C.C.; Yen, C.F.; Jang, F.-L.; Su, J.A.; Lin, C.Y. Comparing affiliate stigma between family caregivers of people with different severe mental illness in Taiwan. J. Nerv. Ment. Dis. 2017, 542-549. [CrossRef]

24. Chang, C.C.; Su, J.A.; Lin, C.Y. Using the Affiliate Stigma Scale on caregivers of people with dementia: Psychometric evaluation. Alzheimer's Res. Ther. 2016, 8, 45. [CrossRef]

25. Chang, C.C.; Su, J.A.; Tsai, C.S.; Yen, C.F.; Liu, J.H.; Lin, C.Y. Rasch analysis suggested three unidimensional domains for Affiliate Stigma Scale: Additional psychometric evaluation. J. Clin. Epidemiol. 2015, 68, 674-683. [CrossRef] 
26. Chang, C.C.; Su, J.A.; Chang, K.C.; Lin, C.Y.; Koschorke, M.; Rüsch, N.; Thornicroft, G. Development of the Family Stigma Stress Scale (FSSS) for detecting stigma stress in caregivers of people with mental illness. Eval. Health Prof. 2019, 42, 148-168. [CrossRef] [PubMed]

27. Chan, Y.; Chan, Y.Y.; Cheng, S.L.; Chow, M.Y.; Tsang, Y.W.; Lee, C.; Lin, C.Y. Investigating quality of life and selfStigma in Hong Kong children with specific learning disabilities. Res. Dev. Disabil. 2017, 68, 131-139. [CrossRef] [PubMed]

28. Lin, C.Y.; Oveisi, S.; Burri, A.; Pakpour, A.H. Theory of Planned Behavior including selfStigma and perceived barriers explain helpSeeking behavior for sexual problems in Iranian women suffering from epilepsy. Epilepsy Behav. 2017, 68, 123-128. [CrossRef]

29. Fung, X.C.C.; Pakpour, A.H.; Wu, K.Y.; Fan, C.W.; Lin, C.Y.; Tsang, H.H.W. Psychosocial variables related to weight-related selfStigma in physical activity among young adults across weight status. Int. J. Environ. Res. Public Health 2019, 17, 64. [CrossRef] [PubMed]

30. Ahorsu, D.K.; Lin, C.Y.; Imani, V.; Griffiths, M.D.; Su, J.A.; Latner, J.D.; Marshall, R.D.; Pakpour, A.H. A prospective study on the link between weight-related selfStigma and binge eating: Role of food addiction and psychological distress [Epub ahead of print]. Int. J. Eat. Disord. 2020. [CrossRef]

31. Lin, C.Y.; Tsai, M.C.; Liu, C.H.; Lin, Y.C.; Hsieh, Y.P.; Strong, C. Psychological pathway from obesity-related stigma to depression via internalized stigma and self-esteem among adolescents in Taiwan. Int. J. Environ. Res. Public Health 2019, 16, 4410. [CrossRef]

32. Alimoradi, Z.; Golboni, F.; Griffiths, M.D.; Broström, A.; Lin, C.Y.; Pakpour, A.H. Weight-related stigma and psychological distress: A systematic review and metaAnalysis [Epub ahead of print]. Clin. Nutr. 2019. [CrossRef]

33. Lin, C.Y. Weight stigma, coping strategies, and mental health among children with overweight. Soc. Health Behav. 2019, 2, 133-138. [CrossRef]

34. Lin, C.Y.; Imani, V.; Cheung, P.; Pakpour, A.H. Psychometric testing on two weight stigma instruments in Iran: Weight SelfStigma Questionnaire and Weight Bias Internalized Scale. Eat. Weight Disord. 2019. [CrossRef]

35. Chan, K.L.; Lee, C.S.C.; Cheng, C.M.; Hui, L.Y.; So, W.T.; Yu, T.S.; Lin, C.Y. Investigating the relationship between weight-related selfStigma and mental health for overweight/obese children in Hong Kong. J. Nerv. Ment. Dis. 2019, 207, 637-641. [CrossRef]

36. Pakpour, A.H.; Tsai, M.C.; Lin, Y.C.; Strong, C.; Latner, J.D.; Fung, X.C.C.; Lin, C.Y.; Tsang, H.W.H. Psychometric properties and measurement invariance of the Weight SelfStigma Questionnaire and Weight Bias Internalization Scale in Hongkongese children and adolescents. Int. J. Clin. Health Psychol. 2019, 19, 150-159. [CrossRef] [PubMed]

37. Lin, C.Y.; Strong, C.; Latner, J.D.; Lin, Y.C.; Tsai, M.C.; Cheung, P. Mediated effects of eating disturbances in the association of perceived weight stigma and emotional distress [Epub ahead of print]. Eat. Weight Disord. 2019. [CrossRef] [PubMed]

38. Cheng, M.Y.; Wang, S.M.; Lam, Y.Y.; Luk, H.T.; Man, Y.C.; Lin, C.Y. The relationships between weight bias, perceived weight stigma, eating behavior and psychological distress among undergraduate students in Hong Kong. J. Nerv. Ment. Dis. 2018, 206, 705-710. [CrossRef] [PubMed]

39. Wong, P.C.; Hsieh, Y.P.; Ng, H.H.; Kong, S.F.; Chan, K.L.; Au, T.Y.A.; Lin, C.Y.; Fung, X.C.C. Investigating the selfStigma and quality of life for overweight/obese children in Hong Kong: A preliminary study. Child Indic. Res. 2019, 12, 1065-1082. [CrossRef]

40. Lee, R.S.; Kochman, A.; Sikkema, K.J. Internalized stigma among people living with HIVAIDS. AIDS Behav. 2002, 6, 309-319. [CrossRef]

41. Parker, R.; Aggleton, P. HIV and AIDS-related stigma and discrimination: A conceptual framework and implications for action. Soc. Sci. Med. 2003, 57, 13-24. [CrossRef]

42. Visser, M.J.; Kershaw, T.; Makin, J.D.; Forsyth, B.W. Development of parallel scales to measure HIV-related stigma. Aids Behav. 2008, 12, 759-771. [CrossRef] [PubMed]

43. Hayes, S.C.; Luoma, J.B.; Bond, F.W.; Masuda, A.; Lillis, J. Acceptance and commitment therapy: Model, processes and outcomes. Behav. Res. Ther. 2006, 44, 1-25. [CrossRef] [PubMed]

44. Switaj, S.; Ggrygiel, P.; Chrostek, A.; Nowak, I.; Wciórka, J.; Anczewska, M. The relationship between internalized stigma and quality of life among people with mental illness: Are self-esteem and sense of coherence sequential mediators? Qual. Life Res. 2017, 26, 2471-2478. [CrossRef] 
45. Post, F.; Pardeller, S.; FranjoApor, B.; Kemmler, G.; Sodermann, C.; Hausmann, A.; Fleischhacker, W.; Mizuno, Y.; Uchida, H.; Hofer, A. Quality of life in stabilized outpatients with bipolar I disorder: Associations with resilience, internalized stigma, and residual symptoms. J. Affect. Disord. 2018, 238, 399-404. [CrossRef]

46. Branscombe, N.R.; Schmitt, M.T.; Harvey, R.D. Perceiving pervasive discrimination among African Americans: Implications for group identification and well-being. J. Pers. Soc. Psychol. 1999, 77, 135-149. [CrossRef]

47. Bogart, K.R. Disability identity predicts lower anxiety and depression in Multiple Sclerosis. Rehabil. Psychol. 2015, 69, 105-109. [CrossRef] [PubMed]

48. Cronin, T.; Levin, S.; Branscombe, N.R.; van Laar, C.; Tropp, L.R. Ethnic identification in response to perceived discrimination protects well-being and promotes activism: A longitudinal study of Latino college students. Group Process. Intergroup Relat. 2012, 15, 393-407. [CrossRef]

49. Garstka, T.A.; Schmitt, M.T.; Branscombe, N.R.; Hummert, M. How young and older adults differ in their responses to perceived age discrimination. Psychol. Aging 2004, 19, 326-335. [CrossRef]

50. Leonardelli, G.J.; Tormala, Z.L. The negative impact of perceiving discrimination on collective well-being: The mediating role of perceived ingroup status. Eur. J. Soc. Psychol. 2003, 33, 507-514. [CrossRef]

51. Armenta, B.E.; Hunt, J.S. Responding to societal devaluation: Effects of perceived personal and group discrimination on the ethnic group identification and personal self-esteem of Latino/Latina adolescents. Group. Process. Intergroup Relat. 2009, 12, 23-39. [CrossRef]

52. Bourguignon, D.; Seron, E.; Yzerbyt, V.; Herman, G. Perceived group and personal discrimination: Differential effects on personal self-esteem. Eur. J. Soc. Psychol. 2006, 36, 773-789. [CrossRef]

53. Fernández, S.; Branscombe, N.R.; Gómez, Á.; Morales, J.F. Influence of the social context on use of surgical-lengthening and group-empowering coping strategies among people with dwarfism. Rehabil. Psychol. 2012, 57, 224-235. [CrossRef]

54. Eccleston, C.P.; Major, B.N. Attributions to discrimination and self-esteem: The role of group identification and appraisals. Group Process. Intergroup Relat. 2006, 9, 147-162. [CrossRef]

55. Fuster-Ruiz de Apodaca, M.J.; Molero, F.; Holgado, F.P.; Mayordomo, S. Enacted and internalized stigma and quality of life among people with HIV: The role of group identity. Qual. Life Res. 2014, 23, 1967-1975. [CrossRef]

56. Ellemers, N. Individual upward mobility and the perceived legitimacy of intergroup relations. In The Psychology of Legitimacy; Jost, T., Major, B., Eds.; Cambridge University Press: Cambridge, UK, 2001.

57. Stürmer, S.; Simon, B. Collective action: Towards a dualPathway model. Eur. Rev. Soc. Psychol. 2004, 15, 59-99. [CrossRef]

58. Stürmer, S.; Simon, B. The role of collective identification in social movement participation: A panel study in the context of the German gay movement. Pers. Soc. Psychol. Bull. 2004, 30, 263-277. [CrossRef] [PubMed]

59. Dirth, T.P.; Branscombe, N.R. The social identity approach to disability: Bridging disability studies and psychological science. Psychol. Bull. 2018. [CrossRef] [PubMed]

60. Moriano, J.A.; Molero, F.; Topa, G.; Lévy Mangin, J.P. The influence of transformational leadership and organizational identification on intrapreneurship. Int. Entrep. Manag. J. 2014, 10, 103-119. [CrossRef]

61. Molero, F.; Fuster, M.J.; Jetten, J.; Moriano, J.A. Living with HIV/AIDS: A psychosocial perspective on coping with prejudice and discrimination. J. Appl. Soc. Psycho. 2011, 41, 609-626. [CrossRef]

62. Nouvilas-Pallejá, E.; Silván-Ferrero, P.; Fuster-Ruiz de Apodaca, M.J.; Molero, F. Stigma consciousness and subjective well-being in lesbians and gays. J. Happiness Stud. 2017, 19, 1115-1133. [CrossRef]

63. Nario-Redmond MR Oleson, K.C. Disability group identification and disability-rights advocacy: Contigencies among emerging and other adults. Emerg. Adulthood 2016, 4, 207-218. [CrossRef]

64. Migerode, F.; Maes, B.; Buysse, A. Quality of life in adolescents with a disability and their parents: The mediating role of social support and resilience. J. Dev. Phys. Disabil. 2012, 24, 487-503. [CrossRef]

65. Grotberg, E. A Guide to Promoting Resilience in Children: Strengthening the Human Spirit. Available online: https://files.eric.ed.gov/fulltext/ED383424.pdf (accessed on 16 January 2020).

66. Davydov, D.M.; Stewart, R.; Ritchie, K.; Chaudieu, I. Resilience and mental health. Clin. Psychol. Rev. 2010, 30, 479-495. [CrossRef]

67. Richardson, G.E. The metatheory of resilience and resiliency. J. Clin. Psychiatry 2002, 58, 307-321. [CrossRef]

68. Richardson, G.E.; Waite, P.J. Mental health promotion through resilience and resiliency education. Int. J. Emerg. Ment. Health 2002, 4, 65-75. 
69. Suriá, R.; García, J.M.; Ortigosa, J.M. Perfiles resilientes y su relación con las habilidades sociales en personas con discapacidad motora. Psicología Conductual 2015, 23, 35-49.

70. Saavedra, E.; Villalta, M. Estudio comparativo en resiliencia con sujetos discapacitados motores. Revista Investigaciones en Educación 2008, 8, 81-90.

71. Uriarte, J.D. La perspectiva comunitaria. Psicología Política 2013, 47, 7-18.

72. Vinaccia, S.; Quiceno, J.M.; Moreno, E. Resiliencia en adolescentes. Revista Colombiana de Psicología 2007, 16, 139-146.

73. Fletcher, D.; Hanton, S.; Mellalieu, S.D. An organizational stress review: Conceptual and theoretical issues in competitive sport. In Literature Reviews in Sport Psychology; Hanton, S., Mellalieu, S.D., Eds.; Nova Science: Hauppauge, NY, USA, 2006.

74. Fletcher, D.; Sarkar, M. A Review and Critique of Definitions, Concepts, and Theory. Eur. Psychol. 2013, 18, 12-23. [CrossRef]

75. Luthar, S.S.; Cicchetti, D.; Becker, B. The construct of resilience: A critical evaluation and guidelines for future work. Child Dev. 2000, 71, 543-562. [CrossRef]

76. Cameron, C.A.; Ungar, M.; Liebenberg, L. Cultural understandings of resilience: Roots for wings in the development of affective resources for resilience. Child Adolesc. Psychiatr. Clin. N. Am. 2007, 16, 285-301. [CrossRef]

77. Hofer, A.; Mizuno, Y.; Watelsteiner, F.; Fleischhacker, W.; Frajo-Apor, B.; Kemmler, G.; Mimura, M.; Pardeller, S.; Sondermann, C.; Sizuki, T.; et al. Quality of life in schizophrenia and bipolar disorder: The impact of symptomatic remission and resilience. Eur. Psychiatry 2017, 46, 42-47. [CrossRef]

78. Taylor, S.E.; Stanton, A.L. Coping resources, coping processes, and mental health. Annu. Rev. Clin. Psychol. 2007, 3, 377-401. [CrossRef]

79. Lazarus, R.S.; Folkman, S. Stress, Appraisal, and Coping; SpringerPub: New York, NY, USA, 1984.

80. Rutter, M. Implications of resilience concepts for scientific understanding. Ann. N. Y. Acad. Sci. 2006, 1094, 1-12. [CrossRef] [PubMed]

81. Gooding, P.A.; Hurst, A.; Johnson, J.; Tarrier, N. Psychological resilience in young and older adults. Int. J. Geriatr. Psychiatry 2012, 27, 262-270. [CrossRef] [PubMed]

82. Fletcher, D.; Scott, M. Psychological stress in sports coaches: A review of concepts, theory and research. J. Sports Sci. 2010, 28, 127-137. [CrossRef] [PubMed]

83. Fletcher, D.; Fletcher, J. A meta-model of stress, emotions and performance: Conceptual foundations, theoretical framework, and research directions [Abstract]. J. Sports Sci. 2005, 23, 157-158. [CrossRef]

84. Hofer, M.A. Evolutionary basis of adaptation in resilience and vulnerability: Response to Cicchetti and Blender. Ann. N. Y. Acad. Sci. 2006, 1094, 259-262. [CrossRef] [PubMed]

85. Mizuno, Y.; Hofer, A.; Suzuki, T.; Frajo-Apor, B.; Watelsteiner, F.; Kemmler, G.; Saruta, J.; Tsukinoki, K.; Mimura, M.; Fleischhacker, W.W.; et al. Clinical and biological correlates of resilience in patients with schizophrenia and bipolar disorder: A cross-sectional study. Schizophr. Res. 2016, 175, 148-153. [CrossRef]

86. Wartelsteiner, F.; Mizuno, Y.; Frajo-Apor, B.; Kemmler, G.; Pardeller, S.; Sondermann, C.; Welte, A.; Fleischhacker, W.W.; Uchida, H.; Hofer, A. Quality of life in stabilized patients with schizophrenia is mainly associated with resilience and self-esteem. Acta Psychiatr. Scand. 2016, 134, 360-367. [CrossRef]

87. Feder, A.; Nestler, E.J.; Charmney, D.S. Psychobiology and molecular genetics of resilience. Nat. Rev. Neurosci. 2009, 10, 446-457. [CrossRef]

88. Battalio, S.L.; Silverman, A.M.; Ehde, D.M.; Amtmann, D.; Edwards, K.A.; Jensen, M.P. Resilience and function in Adults with physical disability: An observational study. Arch. Phys. Med. Rehabil. 2017, 98, 1158-1164. [CrossRef]

89. Edwards, K.A.; Alschuler, K.A.; Ehde, D.M.; Battalio, S.L.; Jensen, M.P. Changes in resilience predict function in adults with physical disability: A longitudinal study. Arch. Phys. Med. Rehabil. 2017, 98, 329-336. [CrossRef]

90. Suriá, R. Discapacidad motora y resiliencia: Análisis en función de la edad, grado y etapa en la que se adquiere la discapacidad. Rev. Española Sobre Incapacidad Intelect. 2014, 45, 6-17.

91. Terrill, A.L.; Molton, I.R.; Ehde, D.M.; Amtmann, D.; Bombardier, C.H.; Smith, A.E.; Jensen, M.P. Resilience, age, and perceived symptoms in persons with long-term physical disability. J. Health Psychol. 2014, 1-10. [CrossRef] [PubMed] 
92. Rao, D.; Choi, S.W.; Victorson, D.; Bode, R.; Peterman, A.; Heinemann, A.; Cella, D. Measuring Stigma Across Neurological Conditions: The Development of the Stigma Scale for Chronic Illness (SSCI). Qual. Life Res. 2009, 18, 585-595. [CrossRef] [PubMed]

93. Molero, F.; Recio, P.; García-Ael, C.; Pérez-Garín, D. Consequences of perceived personal and group discrimination against people with physical disability. Rehabil. Psychol. 2019, 64, 212-220. [CrossRef]

94. Silván-Ferrero, P.; Recio, P.; Nouvilas-Pallejà, E. Estigma internalizado en personas con discapacidad: Propiedades psicométricas de la versión reducida de la SSCI. (Internalized stigma in people with disability: Psychometric properties of the reduced versión of the SCCI). In Proceedings of the III International Conference of the Spanish Scientific Society of Psychology and the XIV National conference of Social Psychology, Cuenca, Spain, 4-6 October 2018.

95. Mael, F.; Ashforth, B.E. Loyal from day one: Biodata, organizational identification, and turnover among newcomers. Pers. Psychol. 1995, 48, 309-333. [CrossRef]

96. Connor, K.M.; Davidson, J.R.T. Development of a new resilience scale: The Connor-Davidson resilience scale (CD-RISC). Depress Anxiety 2003, 18, 76-82. [CrossRef]

97. Notario-Pacheco, B.; Solera-Martínez, M.; Serrano-Parra, M.D.; Bartolomé-Gutiérrez, R.; García-Campayo, J.; Martínez-Vizcaino, V. Reliability and validity of the Spanish version of the 10-item Connor-Davidson Resilience Scale (10-item CD-RISC) in young adults. Health Qual. Life Outcomes 2011, 9, 63-68. [CrossRef]

98. Lucas-Carrasco, R. Versión Española del Whoqol; Ergón: Madrid, Spain, 1998.

99. Lucas-Carrasco, R. The WHO quality of life (WHOQOL) questionnaire: Spanish development and validation studies. Qual. Life Res. 2012, 21, 161-165. [CrossRef]

100. Bentler, P.M. EQS 6 Structural Equations Program Manual; Multivariate Software INC: Encino, CA, USA, 2006.

101. Hu, L.; Bentler, P.M. Cutoff criteria for fit indexes in covariance structure analysis: Conventional criteria versus new alternatives. Struct. Equ. Model. A Multidiscip. J. 1999, 6, 1-55. [CrossRef]

102. Su, C.T.; Ng, H.S.; Yang, A.L.; Lin, C.Y. Psychometric evaluation of the Short Form 36 Health Survey (SF-36) and the World Health Organization Quality of Life Scale Brief Version (WHOQOL-BREF) for patients with schizophrenia. Psychol. Assess. 2014, 26, 980-989. [CrossRef]

103. Brown, T.A. Confirmatory Factor Analysis for Applied Research; The Guilford Press: New York, NY, USA, 2006.

104. Kline, R.B. Principles and Practice of Structural Equation Modelling, 3rd ed.; The Guilford Press: New York, NY, USA, 2011.

105. Yiqing, Y.; Ming, W. Psychological resilience and the onset of activity of daily living disability among older adults in china: A nationwide longitudinal analysis. J. Gerontol. Series B 2014, 70, 470-480. [CrossRef]

106. Gifre, M.; del Valle, A.; Yuguero, M.; Gil, I.; Origüen, A.; Monreal, P. La mejora de la calidad de vida de las personas con lesión medular: La transición del centro rehabilitador a la vida cotidiana desde la perspectiva de los usuarios. (Quality of life improvement in people with spinal cord injury: The transition from rehabilitation hospital to the everyday life from users perspective). Athenea Digit. Rev. Pensam. Investig. Soc. 2010, 18, 3-15.

107. Breslow, A.S.; Brewster, M.E.; Velez, B.L.; Wong, S.; Geiger, E.; Soderstrom, B. Resilience and Collective Action: Exploring Buffers Against Minority Stress for Transgender Individuals. Psychol. Sex. Orientat. Gend. Divers. 2015, 2, 253-265. [CrossRef]

108. Levine, S. The changing terrains in medical sociology: Emergent concern with quality of life. J. Health Soc. Behav. 1987, 28, 1-6. [CrossRef]

109. Albrecht, G.L.; Devlieger, P.J. The disability paradox: High quality of life against all odds. Soc. Sci. Med. 1999, 48, 977-988. [CrossRef]

110. Pérez-Garín, D.; Recio, P.; Silván-Ferrero, P.; Nouvilas, E.; Fuster-Ruiz de Apodaca, M.J. How to cope with disability: Development and psychometric properties of the Coping with Disability Difficulties Scale (CDDS). Rehabil. Psychol. 2019. [CrossRef]

111. Hayes, S.C.; Levin, M.E.; Plumb-Vilardaga, J.; Villatte, J.L.; Pistorello, J. Acceptance and commitment therapy and contextual behavioral science: Examining the progress of a distinctive model of behavioral and cognitive therapy. Behav. Ther. 2013, 44, 180-198. [CrossRef]

112. McCracken, L.M.; Vowles, K.E. Acceptance and commitment therapy and mindfulness for chronic pain: Model, process, and progress. Am. Psychol. 2014, 69, 178-187. [CrossRef]

113. Vowles, K.E.; McCracken, L.M. Acceptance and values-based action in chronic pain: A study of treatment effectiveness and process. J. Consult. Clin. Psychol. 2008, 76, 397-407. [CrossRef] 
114. Bradshaw, B.; Richardson, G.E.; Kunmpfer, K.; Carlson, J.; Stanchfield, J.; Overall, J.; Brooks, A.M.; Kulkarni, K. Determining the efficacy of a resiliency training approach in adults with type 2 diabetes. Diabetes Educ. 2007, 33, 650-659. [CrossRef]

115. Steinhardt, M.A.; Brown, S.A.; Dubois, S.K.; Harrison, L.J.; Lehrer, H.M.; Jaggars, S. A resilience intervention in African-American adults with type 2 diabetes. Am. J. Health Behav. 2015, 39, 507-518. [CrossRef] [PubMed]

116. Sadler, E.; Sarre, S.; Tinker, A.; Bhalla, A.; McKevitt, C. Developing a novel peer support intervention to promote resilience after stroke. Health Soc. Care Community 2016, 25, 1590-1600. [CrossRef] [PubMed]

117. Arakkathara, J.G.; Bance, L.O. Promotion of Well-being, Resilience and Stress Management (POWER): An intervention program for mothers of children with intellectual disability: A pilot study. Indian J. Posit. Psychol. 2019, 10, 294-299.

118. Noone, S.J.; Hastings, R.P. Building psychological resilience in support staff caring for people with intellectual disabilities. J. Intellect. Disabil. 2009, 13, 43-53. [CrossRef]

119. Edraki, M.; Haghshenas, M.; Yektatalab, S.; Dehghani, S.M.; Haghpanah, S. The effect of Educationalpsychological Interventions on the Resilience of the Moders of 1-to-3-year-old Children with Chronic Liver Disease Learning to Cirrhosis. Int. J. Pharm. Res. 2018, 10, 222-226.

120. Bonanno, G.A.; Westphal, M.; Mancini, A.D. Resilience to lost and potential trauma. Annu. Rev. Clin. Psychol. 2011, 7, 511-535. [CrossRef]

121. Arrington, E.G.; Wilson, M.N. A re-examination of risk and resilience during adolescence: Incorporating culture and diversity. J. Child. Fam. Stud. 2000, 9, 221-239. [CrossRef]

122. Deb, A. Psychology of resilience. In Psychology Interventions for Health and Well-Being; Misra, G., Ed.; Springer: Berlin/Heidelberg, Germany, 2018.

123. Dymecka, J.; Bidzan, M. Biomedical Variables and Adaptation to Disease and Health-Related Quality of Life in Polish Patients with MS. Int. J. Environ. Res. Public Health 2018, 15, 2678. [CrossRef]

(C) 2020 by the authors. Licensee MDPI, Basel, Switzerland. This article is an open access article distributed under the terms and conditions of the Creative Commons Attribution (CC BY) license (http://creativecommons.org/licenses/by/4.0/). 